\title{
Managing a project portfolio in construction
}

\author{
Lyudmila Babkina, ${ }^{1, *}$, Oksana Skotarenko ${ }^{2,3}$, and Nikolai Vasiliev ${ }^{3}$ \\ ${ }^{1}$ Branch of the Russian Presidential Academy of National Economy and Public Administration under the President of the Russian \\ Federation, Saint Petersburg, Russia \\ ${ }^{2}$ Murmansk Arctic State University,Murmansk, Russia; \\ ${ }^{3}$ Military Academy of Logistical Support named after General of the Army A. V. Khrulyov,Saint Petersburg, Russia
}

\begin{abstract}
The article presents a project portfolio management process in a construction company. It includes projects on management system improvement and support. For instance, a project on management automation for online tracking of client orders at various stages of construction will reduce the time for handling client orders and raise the quality of service. As a result, the company will become more competitive and attractive on the construction market.
\end{abstract}

\section{Introduction}

In Russia, construction is regulated by the Urban Planning Code of the Russian Federation [1], the Federal Law "On investment activities in the Russian Federation in the form of capital investment" [2], the government programmes for providing Russian citizens with affordable and comfortable housing and utilities [3], and the national programme "Digital economy of the Russian Federation" regulating a digital environment [4].

The Russian authors studying the issues of construction in Russia include Babkina, L. N., Skotarenko, O. V. [5], Balabenko, E. V. [6], Gafurov, A. R., Plotnikov, V. A. [7]; Tatrinov, T. [8], and Trufanov, A. N. $[9,10]$.

The goal of the study is to provide recommendations on building and improved management of a project portfolio in a construction company.

The study methods include a comprehensive, programme-goal, and process-based methodological approach and the methods of analysis, synthesis, and iteration.

\section{Results and discussion}

The construction company builds residential and public buildings for Russian people and restores and repairs cultural and historical heritage sites.

The construction company's mission is to operate for public benefit, on its own or with reliable partners, in the following areas: building standard, specialised, and conceptual projects in a stable environment, i.e. with the required engineering, transport, and social infrastructure, taking into account the climatic, geographical and natural specifics of the area; turnkey construction of any buildings, facilities, and complexes; creating a modern infrastructure and comfortable environment with new, hi-tech equipment for the facilities; housing maintenance.

Managing a construction company requires a symbiosis of advanced construction technologies with the art of handling unique management tasks within the budget provided. Such a symbiosis can be based on project portfolio management.

Planning is a major function of any management system. Project planning in a construction company therefore means a set of related iterations resulting in a document: a master plan as a combination of specific activities to be established at several stages of approvals and adjustments [1].

The plan is the main (core) element of the project management system. It contains all the required parameters for each project, depending on a number of project activities. The main parameters of all projects include the deadline, performers (staff), costs, funding sources, results, and forms and intervals of supervision. The plan also includes a description of the communications and probable risks for each project.

Such planning is project-based, and it sets a framework for better performance of the management system as a whole, achieving the following objectives: clarify and adjust the goals of all plans, detail the results of specific current activities, determine and approve the work scope for all plans, make a plan and budget for the main stages or the whole project, carry out an adjusted needs assessment for all resources for each plan and the whole master plan, make a procurement plan for all resources, explain the details of the current specific activity to the client, agree the plan with the main performers, distribute the responsibility for each specific current activity and the results thereof between the performers, and approve the master plan.

Risk planning and management (identification and assessment) affect both the master plan development and the financial needs (budget). Sufficient project planning

\footnotetext{
*Corresponding author: lnbabkina 6@ mail.ru
} 
is based on clarified goals, quantitative limits for the achievement criteria of specific activities, and a structured performance team with distribution of responsibilities. (Fig.1).

Main project planning processes:

1. The project content selection is done to clarify the project scope in terms of time, cost, and expected quantitative limits of the end result (product). The process starts at determining the goal of each project in connection with the main strategic goal and areas of the company and its management system. Different approaches or goal achievement options are considered. The project developers have to have a clear understanding what work is beyond the project scope and what the requirements to the final product are.

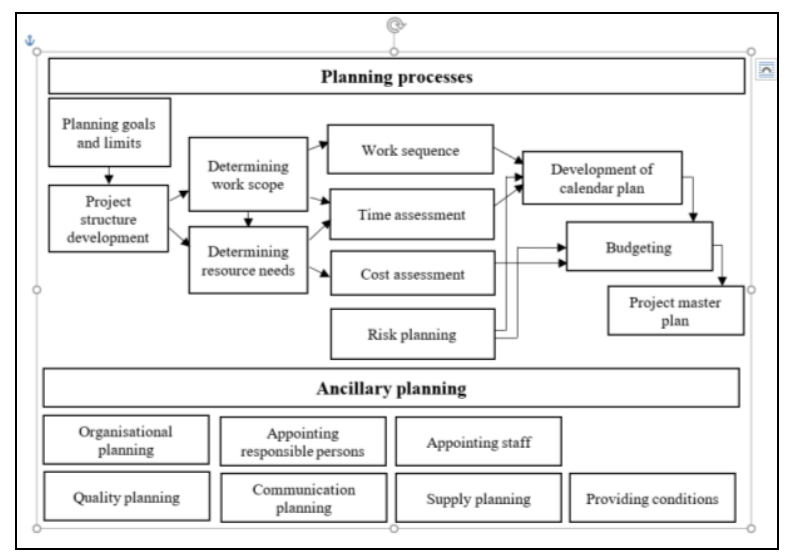

Fig. 1.Model of project management planning in a construction company.

2. Determining which departments will participate in the project development and implementation. The main goals determined in the previous process are developed into plans and specific activities to the full scope required for successful implementation. Their structure and composition are aimed at the main project goal. Such a properly-built fragment of a goal-orientated management system is a vital project management tool.

3. Determining the relations between different plans and involved departments in space and time. The subject and goal of the process mean building a logical sequence of planning and implementation of specific activities. The best tool for and result of the process is a network graph or a network model presented as an optimised diagram.

4. Work duration adjustment. Planning the duration of each (specific) activity included in the network model is based on various methods of assessment: using comparable examples, top-down, performer feedback, expert feedback, and parameter compliance.

5. Resource needs assessment. The goal is to identify the scope of all resources: labour, materials, financial, information, and key assets (construction equipment, machinery, and office equipment).

6. Development of a calendar plan is done for scheduling the (specific) activities and project as a whole. It is essential to provide sufficient detail for the project manager to supervise the implementation of the (specific) activities and project performance as a whole.
7. Development of a master plan for the project. It unites all the planning of specific activities into a single project document.

Those procedures can therefore be viewed as a single management process with a comprehensive package of procedures and documents to create a project plan.

The process is approved for all projects included in the project portfolio. It now contains three things: a construction development portfolio, a security improvement portfolio, and a portfolio of IT development in the management system.

The construction development portfolio is aimed at the main goal of the construction company, which is to satisfy the growing public demand for modern housing and social infrastructure in any part of the country (remote, seismically active, mountainous, desert, and permafrost areas) based on development and implementation of sustainable projects.

The construction development portfolio includes related projects in order to reach the goal, For example, the company branch for structural building has introduced a new technology for BS-5 series of prefabricated buildings. On the real estate market, flats in houses built with those prefabricated panels cost less and have higher quality compared with other new houses.

The security improvement portfolio is aimed at using the applicable copyright law in design and construction and the regulations on quality of service. Such a security improvement portfolio is a considerable competitive advantage attracting new clients.

The IT development portfolio includes a major project on real-time automation of management supervision. The project is aimed at online tracking of client orders at various stages of construction. The information will reduce the time it takes to complete clients' orders, which will help increase the scope and number of orders and therefore boost productivity.

A standard lifecycle of project portfolio management can be shown as follows (Fig. 2).

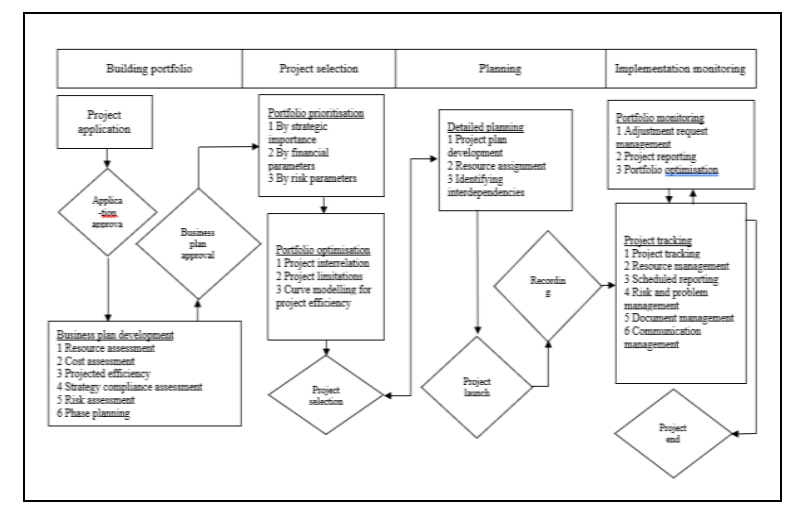

Fig. 2.Standard project portfolio lifecycle.

As shown in Fig. 2, a lifecycle consists of four phases. The first phase - building a project portfolio includes filing an application and developing and approval of main business plan sections. At the second phase, the projects are prioritised using three indicators: strategic importance, financial indicators, and risk 
parameters as well as suitability criteria based on identification of project interrelation, portfolio limitations, and curve modelling of project efficiency. The third planning phase consists of developing project plans, allocation of all resources, and identification of interdependencies of the projects and their results. The phase also includes recording of the base plan. At the fourth phase, the project implementation is managed on the basis of two procedure groups. First, it is project monitoring, including management of requests for adjustment, project status reporting, and optimisation. Secondly, it is project tracking that includes resource management, scheduled reporting, risk and problem management, document management, and communication management.

Unlike individual projects, where the project managers are the actors, project portfolio management is primarily orientated at middle and senior management, i.e. those who make decisions on whether to invest in a particular project. Investment optimisation is a matter of efficiency of the business as a whole, and companies are increasingly applying portfolio management principles to all projects, including IT-related ones. ITbased project portfolio management has to be integrated in the management system due to the following: the lack of experience in using advanced IT in the company and other similar construction companies and the need to plan maintenance costs for the new technology, such as servicing, support, integration with other systems, projects, and products, and follow-up upgrades.

Thus, when choosing the areas of IT investment, we have to take into account a variety of factors to make a decision. Consequently, when deciding on investing in IT-based projects, we have to focus on assessing the degree (influence) of factors determining the risk, cost, and value of the project for the management system and the business as a whole. Those factors have to be identified in advance, assessed, prioritised, and balanced in an IT project portfolio. The problem is that the factors may conflict within one or more projects. Therefore, the main objective of IT portfolio management is to balance the project parameters in the portfolio.

In order to manage the portfolio, the company has developed an information technology development strategy within its management system (IT strategy). The critical success factor for the strategy is whether it accounts for the actual needs of the management system and the company as a whole for information technologies and the relevant objectives of the IT Department.

Each project in the IT portfolio is aimed at the goals and objectives specified in the IT strategy. It is the IT strategy that determines the rules and priorities for inclusion of IT projects in the portfolio.

The main goal of a project portfolio is to create a complex (pool) of projects that can be potentially launched and implemented.

Let us view the algorithm for building a project portfolio, which normally has several stages. At the first stage, main strategic goals of the company are approved. At the second stage, condition goals or strategic areas are determined for the company's management system.
Those have to be implemented so as to achieve the main strategic goal of the company and its management system.

A project portfolio is built at the third stage. The portfolio can be viewed as a combination or programme goals or strategic activities. It is at this stage when project (investment) proposals and applications are collected without financial or other restrictions.

However, it often happens that, while a project portfolio is being implemented as a combination of programme goals, some of the projects lack a connection to the strategic goals for which the projects are to be developed and implemented.

It therefore becomes necessary to do a reverse task and identify which condition goals the existing projects on the list are aimed at.

The IT Department of the construction company in question is currently implementing twelve projects to reach four goals that can be called strategical areas of the management system: standardise the equipment, standardise the working environment, improve the quality of service, and consolidate the equipment.

Four projects are aimed at standardising the equipment: support of the equipment in line with the new working regulations, replacement of the servers with new ones, and migration of the equipment and architecture to higher-performance hardware. The goal of standardising the working environment means development and implementation of three projects: database consolidation, keeping track of the server rooms, and upgrading the workplace software. The goal of improving the quality of service can be reached by development and implementation of three projects: mail archiving, comprehensive process monitoring, and file archiving. The goal of consolidating the equipment means development and implementation of two projects: virtualisation of servers and migration of the equipment acquired from the data centre (DC).

The next stage is to determine the goals and criteria to be achieved by implementation of the said projects and compare them with the goals and criteria set in the approved strategy, projects, and development plans of the construction company.

The goal can be formulated as follows: reduce the operational costs of supporting the IT infrastructure, reduce the number of failures in the IT infrastructure, and build customer loyalty.

For example, the cost reduction in the IT infrastructure support is achieved by specific activities in the projects for standardisation of the equipment, standardisation of the working environment, and consolidation of the equipment. The number of failures in the IT infrastructure can be reduced by standardisation of the equipment. Customer loyalty can be built by improving the quality of service.

We can therefore make certain conclusions. The project for standardising the equipment is the most important as it is aimed at two goals. The number of failures in the IT infrastructure cannot be reduced by just one project. The rule of breaking down goals into subgoals requires implementation of at least two projects, which means another one has to be developed. To do 
that, we had to analyse the failures and identify the functions where failures appeared most frequently. The analysis has shown that most of the failures occurred in the network infrastructure. There has appeared a need to develop and implement a project to upgrade the network infrastructure in order to reduce the number of failures in the IT infrastructure.

The same is true for the goal of increasing customer loyalty, when there is only one project to be implemented.

A project portfolio is a combination of related projects aimed at achieving results and efficiency. Portfolio management is a complex process of selecting and implementing ideas that bring the best results and efficiency in a changing internal and external environment. It is therefore obvious that the goal of increasing customer loyalty, with its approved strategy lacking a second project, has to be analysed as well.

A new portfolio management strategy is therefore needed.

\section{Conclusions}

The most important academically-relevant, theoretically and practically important findings are as follows.

Project portfolio management should be viewed as an IT-backed complex of stages, procedures, and lifecycle phases.

First, efficient portfolio management gives opportunities for innovation-based strategic advantages united in a corporate project portfolio. Secondly, not only does it help achieve the goals and objectives, but also raises the productivity of the staff involved. Thirdly, activities of a construction company become transparent, easily controllable, and manageable. Fourthly, higher quality of project management remains an important and essential competitive factor making it possible to react to market demand and use the internal capacity efficiently and dynamically.

Project portfolio management therefore means centralised management of processes, methods, and technologies to be used by the project managers for analysis and joint management of ongoing or proposed projects based on a range of indicators: parameters and properties. They are critical for company's competitiveness on the construction market.

The practical value of a project portfolio of a construction company is determined by its capacity to create and build a competitive advantage. However, the resources available for all activities remain a natural limitation.

Project portfolio optimisation means finding a link between the strategic goals and the ongoing projects. It should be aimed at attracting more investment and at manageability of the projects in the portfolio.

The suggested method will help the IT Department focus on the projects that directly determine whether the company's strategic goals will be achieved.

In general, project portfolio management should be based on the principles of realism, suitability, flexibility, applicability, and feasibility.
Realism means analysing and taking into account the real conditions for project decision-making, including the multiple and conflicting company goals and the existing limitations of time and resources.

Suitability has to ensure that a suitable solution is chosen, taking into account all benefits and risks of individual projects and the portfolio as a whole as well as the company's costs and existing limitations.

Flexibility means not just a high degree of consistency of the project solutions with the current small-scale and large-scale external and internal environments where the company is operating, but also fast adaptability to change in those environments.

Applicability means that portfolio management does not use difficult-to-obtain statistical or reporting data or special resources unavailable to the company.

Feasibility means that the costs of information collection and processing do not exceed the benefits of using portfolio management.

\section{References}

[1] Urban Planning Code of the Russian Federation, 190-FZ (29 December 2004) (In Russian)

[2] On investment activities in the Russian Federation in the form of capital investment: Federal Law, 39FZ (25 February 1999) (In Russian)

[3] On approval of the government programme for providing Russian Federation citizens with affordable and comfortable housing and utilities: RF Government Decree, 1710 (30 December 2017) (In Russian)

[4] Data sheet of the federal project for regulation of a digital environment within the national programme for a digital economy in the Russian Federation: approved by the Executive Board of the Government Commission for Digital Development and Information Technology for Improvement of the Living Standards and Condition $s$ for Doing Business [Electronic resource] (28 May 2019) Available at: https://digital.gov.ru (In Russian)

[5] L.N. Babkina, O.V. Skotarenko, Dinamika razvitiya stroitelstva v Severo-Zapadnomregione Rossiyskoy Federatsii [Dynamics of construction development in the North-Western region of the Russian Federation], Izvestiyavuzov, Investitsii, Stroitelstvo, Nedvizhimost $=$ University News, Investment, Construction, Real Estate, Irkutsk, Publishing Department of Irkutsk National Technological Research University 8, 2 (21), 18-30 (2018) (In Russian)

[6] E.V. Balabenko, Metodicheskiy podkhod k otsenke effektivnosti ispolzovaniya territorii dlya zhilishchnogo stroitelstva [A methodological approach to assessment of efficient land use for residential construction], Izvestiyavuzov, Investitsii, Stroitelstvo, Nedvizhimost = University News, Investment, Construction, Real Estate 7, 4, 21-39 (2017) (In Russian) 
[7] A.R. Gafurov, V.A. Plotnikov, O.V. Skotarenko, Improvement of the cost-benefit analysis algorithm for high-rise construction projects, E3S Web of Conferences 33, 030732017 (6 March 2018)

[8] International Scientific Conference on High-Rise Construction, HRC 2017, Samara State Technical University (SamGTU), Samara, Russian Federation, (4 September 2017 to 8 September 2017)

[9] T. Tatrinov, Tsifrovizatsiya stroitelnoy otrasli: mesto Rossii v mirovykh tendentsiyakh na primere kontrolya stroitel'stva [Digitasilation of construction: the place of Russia in the global trends - a case study of construction supervision] [Electronic resource] Available at: https://sapr.ru/article/25580 (In Russian)

[10]A.N. Trufanov, Inzhenerno-geologicheskie i geotekhnicheskie I zyskaniya pri vysotnom stroitelstve: avtorskaya lektsiyana 100+ Forum Russia [Geological and technological geo-survey in high-rise construction: an author's lecture at 100+ Forum Russia] [Electronic resource] (2016) Available at: https://www.geoinfo.ru/product/trufanov-aleksandrnikolaevich/inzhenerno-geologicheskie-igeotekhnicheskie-izyskaniya-pri-vysotnomstroitelstve-br-avtorskaya-lekciya-na-100-forumrussia-2016-34889.shtml (In Russian)

[11] Stroitel'stvo vysotnykh zdaniy: nyuansy i etapy vozvedeniya [High-rise construction: nuances and construction stages] [Electronic resource] Available at: http://stroimprosto-msk.ru/stati/stroitelstvovysotnyx-zdanij-nyuansy-i-etapy-vozvedeniya (In Russian) 